\title{
Cultura e tecnologia: a constituição do serviço telegráfico no Brasil*
}

Laura Antunes Maciel UNESP - Assis

\section{RESUMO}

Acompanhando a emergência da comunicação telegráfica como um ramo da administração pública, este artigo aborda os movimentos em direção à sua organização burocrático administrativa em todo o território nacional, recupera experiências em torno de sua modernização técnica e discute algumas questões sobre o papel do Estado no que se refere à regulamentação das telecomunicações.

Palavras-chave: telégrafo; cultura; administração pública.

\section{ABSTRACT}

Following the emergence of the telegraphic communication as a branch of the public administration, this article approaches the movements in route to its bureaucratic-administrative organization in the national territory, recoveres experiences around its modernization technique and discusses some questions about the function of the State refer to the regulation of the telecommunications.

Keywords: telegraph; culture; public administration.

Previsões feitas desde os primeiros anos do século XX acenavam com objetos técnicos - telégrafos portáteis, carros voadores, robôs domésticos, etc. - que nos dispensariam do trabalho pesado e repetitivo, facilitariam os deslocamentos e agilizariam ao máximo a comunicação. Esse era o futuro imaginado no passado. No início de um novo milênio, não temos ainda carros voadores nem robôs na cozinha, os últimos aparelhos de telégrafo estão sendo substituídos definitivamente, mas o rádio, o telefone celular e a Internet alimentam os sonhos de enviar e receber informações a qualquer momento e de qualquer lugar.

Considerado hoje o modo de comunicação ancestral da Internet, o telégrafo foi a primeira tecnologia de informação utilizada em rede mundial. Sua difusão e seu desenvolvimento criaram uma cultura própria, com vocabulário, linguagem, ritmo e formas de comunicar compartilha- 
dos por milhões de pessoas em todo o mundo. Ao longo de um século e meio, o telégrafo incorporou-se ao cotidiano ao lado de outros sistemas tradicionais de comunicação ainda hoje em uso, como o telefone e o rádio, por exemplo. Acima de tudo, o telégrafo transformou a forma de comunicar e informar, acelerou o tempo vivido, apressou a circulação das notícias e, principalmente, mudou o modo de descrever os acontecimentos. Após sua apropriação pela imprensa empresarial - por meio de seções para notícias telegráficas, a colaboração de correspondentes e a compra de informações via agências internacionais de notícias -, os leitores de periódicos não teriam mais paciência ou interesse para longos relatos, dados minuciosos sobre local, personagens, sentimentos, etc. Depois do telégrafo, a notícia seria breve, seca, rápida, telegráfica.

Em meados do século XIX, o telégrafo elétrico foi apresentado aos brasileiros como uma tecnologia engenhosa capaz de transportar o pensamento humano através do ar, por meio da eletricidade. Levadas por fios metálicos e condutores, as idéias poderiam circular rapidamente pelos lugares mais distantes impulsionadas pelo "fluido elétrico". Surgia um invento técnico que prometia encolher o mundo e transportar mensagens através de continentes e oceanos, numa velocidade de 25 mil quilômetros por segundo. Em 1905, passados apenas cinqüenta e três anos do início da telegrafia no país, um engenheiro da Repartição Geral de Telégrafos-RGT já dava como concluída a "rede de arames" que permitiria a um telegrama fazer a volta ao mundo em apenas nove minutos:

Em nossos dias os países civilizados estão cobertos por uma verdadeira rede de arames estendidos entre postes e condutores subterrâneos, e os continentes se acham ligados entre si por cabos mergulhados nas imensas profundidades dos oceanos. Graças a esse gigantesco trabalho, (...) podemos do Brasil acompanhar os acontecimentos que se dão nas mais longínquas terras. (...) A telegrafia e a telefonia progridem, portanto; e, sempre ao serviço da coletividade, colocam as cidades e os Estados longínquos em contato diuturno; aproximam os produtores dos consumidores, a suprema administração do Estado dos funcionários colocados nos confins. São elementos indispensáveis à solidariedade e ao progresso das nações. ${ }^{1}$

Já era possível inserir o Brasil entre os países civilizados detentores de uma moderna tecnologia de informação. O passado recente da implantação do telégrafo já era descrito como um processo acabado e apresentado como uma sucessão de conquistas tecnológicas bem sucedidas. Porém, acompanhar a montagem e constituição dos serviços de comunicação telegráfica no país significa rever um longo processo de experimentação 
empírica de aparelhos, fios e condutores, permeado por frustrações e dúvidas, avanços e recuos, falta de credibilidade e recursos.

Não é minha intenção neste texto fazer uma história da expansão da rede telegráfica brasileira, nem mesmo acompanhar todas as etapas e os avanços na constituição dos serviços telegráficos no país. Ao explorar algumas transformações nos equipamentos e no saber sobre sua operação, não busco traçar uma genealogia do progresso técnico, mas captar a historicidade dessas mudanças, os valores e os significados culturais atribuídos ao telégrafo e à comunicação telegráfica na passagem do século XIX para o XX. Proponho, portanto, uma abordagem sobre o telégrafo e a comunicação telegráfica como objetos técnicos portadores de significados que falam mais da sociedade que os constrói e utiliza, do que da técnica em si mesma.

Nesse sentido, reflito sobre essas questões a partir do entendimento de que os suportes técnicos são linguagens e meios de comunicação sociais, que expressam relações sociais ao mesmo tempo em que são elementos constitutivos da experiência social. Apóio-me em Williams, para quem a linguagem não é "um simples 'reflexo' ou 'expressão' da 'realidade material", mas "uma compreensão dessa realidade através da linguagem, que como consciência prática está saturada por toda atividade social, e a satura, inclusive a atividade produtiva" ${ }^{2}$. A linguagem, assim entendida, é não só resultado de práticas e relações sociais mas também expressão dessas práticas e relações, através das quais o telégrafo e a telegrafia se constituem historicamente. Isto implica trabalhar com a produção da linguagem telegráfica enquanto espaço de disputas, de tensões sociais, e como prática concreta que realiza tarefas de dominação e de poder, ainda que apareça como um dado natural e neutro da vida social. Nessa perspectiva de abordagem da história social, a cultura é pensada como uma categoria e campo de possibilidades para explorar as contradições do social, não como um elemento exterior a ele, mas como "um sistema de significações' de maneira ampla, de modo a permitir a inclusão de todas as práticas e assim definir-se como um 'processo social constitutivo que cria diferentes e específicos modos de vida"’3.

A partir destas questões procurei acompanhar as justificativas para a necessidade de agilizar as comunicações telegráficas de modo a questionar uma memória unívoca - construída por técnicos ligados à RGT - e rastrear razões menos nobres que apontam para a articulação entre modernas tecnologias e modos arcaicos de exploração do trabalho no Brasil. Acompanhando os primeiros passos da instalação dos serviços telegráfi- 
cos no país, encontramos o telégrafo óptico em funcionamento desde 1808, inicialmente sob a jurisdição do Ministério da Guerra e, desde 1838, sob a administração do Ministério da Justiça. As linhas e estações montadas na Corte ligavam as diversas fortalezas dispostas ao longo da barra até a estação central do Castelo e a Quinta da Boa Vista, e tinham por única finalidade anunciar a chegada de embarcações e sua nacionalidade. Desde então, até a introdução do telégrafo elétrico em 1852, os relatórios informam as reiteradas tentativas de sucessivos ministros da Justiça de ampliar a utilidade deste serviço, como elemento cooperador da polícia, por exemplo, além de mostrar o embate por mais verbas necessárias para a manutenção e melhoria do serviço prestado.

Existem nesses relatos muitas referências à falta de verbas para ampliar estudos e experiências, para realizar os menores reparos nas estações desativadas com freqüência, ou para o pagamento de melhores salários que permitissem "escolher homens de inteligência”, já que o vencimento dos funcionários do telégrafo seriam inferiores ao de qualquer servente de obras. Enfim, estava "ainda longe de chegar entre nós este ramo de serviço à perfeição, que seria para desejar”, confessava em 1846 o ministro José Joaquim Fernandes Torres. Ano após ano, nenhuma alteração havia a comunicar sobre o serviço na Corte, nem tampouco sobre as províncias da Bahia, Pernambuco, Ceará, Maranhão e Santa Catarina, que também contavam com este tipo de comunicação.

A partir de 1850, porém, os relatórios do Ministério da Justiça começam a anunciar as experiências realizadas com os telégrafos elétricos, afiançando o grau de perfeição a que os aparelhos haviam chegado, a rapidez permitida pela eletricidade na comunicação de pensamentos e notícias através de maiores distâncias, ao mesmo tempo em que reconhecia "os séculos de atraso" que nos separavam desses benefícios modernos da civilização. No ano seguinte, o ministro Eusébio de Queiroz assim manifestou-se:

Tenho o prazer de anunciar-vos, que dentro de pouco tempo se acharão em exercício os telégrafos elétricos, e ainda que sobre linhas de pequena extensão, considero de grande importância este primeiro ensaio de tão prodigiosa descoberta. A comunicação dos pensamentos, das ordens, das notícias já não encontra demora na distância. ${ }^{4}$

A primeira linha de telégrafo elétrico, concluída em 1852, ligou a Quinta Imperial ao Quartel General do Exército e foi justificada pela necessidade de expedir ordens rápidas para a repressão ao tráfico de escra- 
vos. Coordenada pelo professor Gustavo Schüch Capanema, lente de física da Escola Militar, sua construção utilizou materiais e aparelhos adquiridos em Londres e formas compulsórias de trabalho, lançando mão dos presos da Casa de Correção ${ }^{5}$. Portanto, as primeiras iniciativas para a instalação do telégrafo elétrico no Brasil surgiriam da associação entre a curiosidade de alguns poucos engenheiros e professores das Academias da Corte e as necessidades do governo imperial em agilizar o controle sobre o desembarque de escravos, que acontecia sem maiores atropelos até mesmo nas vizinhanças da Corte.

Durante os primeiros anos, o destino e a aplicação do telégrafo elétrico foi exclusivo do serviço de polícia da Corte, encarregado de analisar os lugares convenientes para a instalação de estações, bem como os locais onde "será colocada a administração do Telégrafo, e a força pública com o duplicado fim de prestar-se à guarnição da estação e serviço de polícia nesses lugares”.6. Em seus primeiros passos, portanto, coube ao telégrafo uma função auxiliar ao serviço de policiamento da Corte, interligando através de suas linhas e estações, a Central de Polícia e todos os quartéis, arsenais da Guerra e Marinha, além do Paço da Cidade e os palácios de São Cristóvão e Petrópolis. Somente cinco anos depois de instalada essa primeira linha o serviço telegráfico seria franqueado a particulares - com a regulamentação do serviço de telegramas pagos -, tendo início a exploração comercial do telégrafo no Brasil.

Por mais uma década ainda a comunicação telegráfica não mereceria a confiança dos habitantes da Corte, que mantiveram inalterado o hábito secular de remeter os recados através de mensageiros. Vítima de preconceitos e reclamações sobre sua ineficiência e até de descrença sobre a possibilidade de trocar mensagens através de um fio eletrificado, o telégrafo não passaria, para muitos, de truque, ilusionismo e efeito de mágica. Estas desconfianças justificariam o pequeno volume de correspondência telegráfica, chegando a ameaçar o fechamento de algumas estações telegráficas.

A utilidade do telégrafo só seria comprovada no "teatro da guerra" com o Paraguai, onde as linhas telegráficas montadas para a campanha mostrar-se-iam eficientes para orientar o rápido avanço das tropas e para a redefinição das estratégias militares. Aqui, ao contrário do que ocorreu na Europa, foi a experiência extrema da guerra que tornou evidente a necessidade de comunicações ágeis para a administração do território. A experiência da guerra evidenciou a precariedade das comunicações com o centro-sul do país, a fragilidade da defesa das fronteiras imperiais e, prin- 
cipalmente, quanto o telégrafo poderia auxiliar na solução desses problemas, o que determinou o início imediato da construção de linhas telegráficas, por iniciativa e sob a responsabilidade da RGT, visando unir e integrar as províncias brasileiras.

A crônica falta de recursos, os "tropeços que a natureza tropical e a vastidão do país" impunham ao desenvolvimento da rede telegráfica, as constantes falhas e interrupções na comunicação, a falta de preparo do pessoal técnico responsável pela administração do telégrafo nacional, além da urgência, por parte do governo imperial, em estabelecer comunicação telegráfica com as províncias e as cada vez mais evidentes possibilidades de exploração e rentabilidade do telégrafo difundiam "a crença de que a telegrafia mantida pelo Estado era impraticável”, aumentando as queixas e reclamações do público, a "antipatia" e a "indisposição quase geral contra o telégrafo" . De outro lado, estes argumentos serviam para justificar a entrada de particulares, individualmente ou organizados em empresas, na disputa pela construção de novas linhas terrestres ou através de cabos fluviais ou submarinos.

A conquista da "telegrafia transatlântica" através de cabo submarino uniu, em 1866, a América à Europa e permitiu que o velho e o novo mundo pudessem conversar, ainda que separados pela imensidão do oceano. No Brasil, esse acontecimento foi apresentado como uma possibilidade para a sua emancipação política e econômica, na medida em que o telégrafo poderia torná-lo "vizinho da Europa", modificando todas as suas relações com o exterior, além de favorecer a "direta comunicação" do governo com seus auxiliares e dos produtores com os consumidores, auxiliando eficazmente o desenvolvimento do país.

Decorridos pouco mais de dez anos da introdução do telégrafo elétrico no Brasil, cujas linhas estendiam-se pouco além dos arredores da Corte, já se sonhava com a comunicação rápida e direta entre as províncias brasileiras e destas com a Europa e a América'. Em 1873, falando às províncias da Bahia, Pernambuco e Pará, por ocasião da inauguração do cabo submarino que ligou as três capitais ao Rio de Janeiro, Pedro II saudou, via telégrafo, esse "tão fausto acontecimento", salientando a importância da "eletricidade [que começava] a ligar as cidades mais importantes deste vasto Império, como o patriotismo reúne (sic) todos os brasileiros no mesmo empenho pela prosperidade da nossa majestosa Pátria". O período entre 1866-1886 é considerado o momento áureo da expansão da rede telegráfica sob o Império. Nesses vinte anos, o Império construiu 10.969 quilômetros de linhas telegráficas ligando 182 estações, capazes 
de "estreitar num sólido e vigoroso laço de fio telegráfico todo o vasto litoral de um ao outro extremo do país". A eletricidade e o fio telegráfico eram pensados, então, como os meios modernos capazes de atar as províncias, costurá-las umas às outras, evitando dessa forma a desagregação do território.

No Império, o telégrafo elétrico impunha-se, cada vez mais, como um elemento técnico inestimável para a solução dos "magnos problemas da administração pública e da segurança nacional", além de constituir um poderoso promotor do desenvolvimento material nas regiões atravessadas pelas linhas telegráficas. Acreditando nos altos desígnios patrióticos inerentes ao telégrafo e na sua função como um serviço público, a RGT apontava a necessidade de expandir a construção e conservação das linhas e, ao mesmo tempo, de proteger o novo invento da exploração industrial desenfreada e gananciosa. Além de permitir a penetração do território e manter a integridade física do Império, o telégrafo deveria, ao mesmo tempo, tornar mais palpável e direto o contato do governo com os seus súditos, aumentando a presença simbólica do imperador, tornada mais eficaz através da difusão de suas palavras, suas ordens e seus atos para todos os recantos. Apesar da extensão das linhas construídas até 1889, cerca de 19 mil quilômetros, a proclamação da República ainda encontrou três províncias - Mato Grosso, Goiás e Amazonas - isoladas do circuito telegráfico brasileiro, inacessíveis ao pensamento e às notícias do restante do país e desarticuladas da vida nacional.

A mudança do regime não provocaria transformações imediatas na orientação e no serviço do telégrafo nacional. Os relatórios anuais da RGT, no entanto, construíram e divulgaram a crença de que a República - assentada no regime federativo e na plena liberdade de expressão, circulação e associação - havia provocado um acréscimo das "forças produtoras" adormecidas, até então, pelo ritmo letárgico do Império. Essa "expansão quase febril do movimento comercial e industrial" teria ocorrido naturalmente com a "transformação política do país" e fez-se sentir no "serviço telegráfico que aumentava aos saltos, chegando a triplicar e quase a quadruplicar" ${ }^{\prime 10}$, fazendo crescer o número de telegramas e de palavras anualmente transportados pelo telégrafo nacional. A República parecia ter pressa em transportar o pensamento de seus cidadãos de um lado a outro do seu território, colocando em comunicação "Estados irmãos" que, até então, teriam ficado à parte da nação brasileira em função da distância e do atraso técnico que os separaria. Essa imagem de velocidade, de ritmo febril na circulação de mercadorias - incluindo-se aí o pensa- 
mento e a palavra -, da necessidade de maior agilidade e mesmo de urgência nas comunicações e trocas, é uma construção do regime republicano autorizada e apoiada pelo telégrafo. Associando o atraso do país à centralização monárquica, a República cunhou uma imagem do Império como sinônimo de estagnação, monotonia e letargia à qual se contrapunha um novo tempo, ágil e vivaz, trazido pela descentralização, pelo regime representativo, pela participação política e pela reunião de Estados autônomos na constituição da nação brasileira. Estas argumentações serviram para cobrar maior agilidade e desempenho das comunicações telegráficas, de modo a atender o rápido crescimento do número de telegramas e promover a interiorização da nação via telégrafo.

Acompanhando os primeiros relatórios administrativos da RGT, é possível identificar as preocupações que moviam seus técnicos e responsáveis: a necessidade de realizar estudos e planos de modificações e melhoramentos para agilizar a comunicação telegráfica e, principalmente, para criar uma padronização técnica do serviço há muito reclamada pelos diretores do órgão. Outro grande problema era superar os constantes defeitos, acidentes e danos intencionais que provocavam interrupções no funcionamento das linhas telegráficas. Entre os incidentes mais comuns nesses relatos estavam a queda de árvores e postes sobre as linhas, quebra de isoladores, pouso de pássaros nas linhas, linhas partidas e/ou com arames enganchados, entre outros, responsáveis pela demora ou interrupção na comunicação. Apesar das multas e prisões previstas no regulamento da RGT e no Código Penal, os acidentes ou a destruição de isoladores, postes e fios eram de tal magnitude que os relatórios apresentavam anualmente mapas estatísticos detalhados dos motivos, locais e o total de horas paralisadas em função das ocorrências notificadas. Em 1900 a RGT já realizava uma contabilidade dos defeitos com um nítido sentido preventivo, organizando mapas com os tipos de problemas mais freqüentes e os locais onde ocorriam, de modo a agilizar os reparos e ensaiar métodos de prevenção. Com base nessas estatísticas, a RGT estabelecia a classificação das estações telegráficas, que variava principalmente em função do volume de telegramas; definia o fechamento de estações com movimento considerado insignificante ou a sua transformação em um posto telefônico, no caso da média mensal da estação ficar muito abaixo de 300 telegramas. Desde 1890, pelo menos, a RGT já trabalhava com esses dados sobre a produção e rentabilidade das estações, de forma a diminuir custos com mão-de-obra, orientar o fechamento de estações ou alocá-las junto com agências postais e/ou telefônicas. 
Segundo os relatórios, muitos dos transtornos nas linhas eram causados pela incompreensão, curiosidade ou ignorância de viajantes e tropeiros que, no interior, arrebentavam os fios, arrancavam ou usavam os isoladores como alvos para sessões de tiro; outros eram danos intencionais aos fios e postes, arrancados para fazer lenha ou, ainda, destruídos às vésperas de eleições para impedir a comunicação entre os municípios. Durante o ano de 1900, por exemplo, somadas todas as ocorrências notificadas, as interrupções computadas na rubrica "acidentes" totalizaram cerca de 20 mil horas de paralisação no serviço telegráfico. Cabe destacar, também, que a contabilidade anual dessas ocorrências permitia à RGT administrar as punições quando os defeitos eram causados por inabilidade dos telegrafistas, no caso dos aparelhos telegráficos, ou pelo descaso dos guarda-fios na fiscalização e reparo das linhas sob sua responsabilidade.

A presença de todos esses temas repetidos ano a ano nos relatórios da RGT indica os passos seguidos no processo de implementação dos serviços telegráficos e na sua constituição como um ramo da administração pública. Tratava-se, nos primeiros anos, de convencer e provar à opinião pública, e também a parcelas do próprio governo, a importância e a viabilidade do telégrafo entre nós, a necessidade de destinar recursos orçamentários para a construção de linhas e o papel que o Estado deveria desempenhar na implantação e exploração da comunicação célere. Ao mesmo tempo, a RGT buscava disciplinar o uso do telégrafo, a expedição de telegramas e o necessário sigilo do seu conteúdo, definindo tarifas inclusive para as linhas exploradas pelas empresas particulares, além de se ocupar com as concessões de autorizações para lançamento de cabos submarinos e construção de linhas terrestres, numa clara demonstração de proteção ao serviço telegráfico oferecido pelo Estado.

Os guias telegráficos publicados e distribuídos pela RGT definiam, para o público usuário, a fiscalização e os limites da responsabilidade do governo no tocante à transmissão de telegramas, bem como os casos em que as mensagens podiam ser anuladas e retidas pelas estações telegráficas. Basicamente, as restrições ligavam-se às questões da linguagem considerada inadequada ou ofensiva, às injúrias, difamações e calúnias, além de atenção especial com mensagens que pudessem contrariar as leis vigentes ou que colocassem em risco a ordem pública. Já para a orientação do pessoal técnico das agências a RGT publicava, através do seu Boletim Telegráfico, instruções de caráter normativo, definindo os procedimentos a serem adotados em cada uma das situações.

Seguindo uma diretriz internacional, desde o Império o governo bra- 
sileiro apostou na popularização do telégrafo, tentando atrair, através da diminuição das taxas, um volume maior de correspondência telegráfica, oferecendo descontos para concorrer com as linhas das estradas de ferro e os cabogramas. Apesar da "tradição monopolizadora" da RGT, defendendo a concentração nas mãos do governo imperial de todo o serviço telegráfico e telefônico, as diretrizes legais durante o Império orientaramse para uma postura mais liberal, próxima da praticada pelos EUA, procurando juntar aos esforços públicos os da iniciativa privada, através de inúmeras concessões de linhas telegráficas terrestres - principalmente às estradas de ferro - e cabos submarinos ou subfluviais costeiros para compor a rede telegráfica nacional.

Essa discussão sobre o papel do Estado no que se refere à normatização das comunicações telegráficas intensificou-se com a Proclamação da República. A RGT deteve-se, particularmente, na regulamentação dos contratos para construção de linhas telegráficas e condutores elétricos por particulares e pelos governos estaduais. Essas questões, até então ausentes do texto constitucional, foram contempladas na primeira constituição republicana, concedendo aos Estados o direito de construir linhas entre os pontos de seus territórios e entre estes e os de outros Estados ain136 da não servidos por linhas federais, resguardando o direito de desapropriação por parte da União quando fosse do "interesse geral". Mantiveram-se, por outro lado, os direitos da União no tocante a medidas de defesa e segurança das linhas federais de telefones e telégrafos e o poder de intervir na construção de quaisquer "canalizações elétricas".

Os constituintes, como ressaltou um administrador da RGT, não consideraram o telégrafo "apenas como instrumento econômico e social mas, principalmente, como um aparelho indispensável ao governo, essencialmente oficial, cabendo à União a responsabilidade integral no tocante à transmissão do pensamento" ${ }^{11}$. Essas orientações foram incorporadas ao segundo regulamento republicano para os telégrafos, datado de 1894, no qual está expressa a competência exclusiva do governo federal para o estabelecimento e exploração de linhas telegráficas interestaduais, resguardando, porém, a possibilidade de o exercício desse direito ser concedido a empresas particulares sob a fiscalização do governo.

A percepção do potencial estratégico do telégrafo, sob o aspecto de instrumento ordenador na transmissão de idéias, mensagens e formas de comunicação, levou a RGT a criar mecanismos capazes de manter a "nacionalização da comunicação telegráfica" e transformá-lo em um monopólio do Estado, a exemplo do que ocorreu na maioria dos países euro- 
peus. A entrada das comunicações para a órbita do "domínio oficial" seria justificada, na opinião de João Barbalho Uchôa Cavalcanti, em função das "preciosas vantagens de ordem, celeridade e discrição" impressas pela administração pública. Além disso, seria impossível garantir que "todas as partes do território nacional [entrassem no] gozo de um serviço regular e garantido", caso os correios e telégrafos fossem abandonados à indústria particular.

Para outro jurista, Viveiros de Castro, as discussões relativas à telegrafia ainda estavam limitadas pela noção de "um monopólio do Estado que, além de incompreendido, [era] contrário aos princípios jurídicos brasileiros", já que não se poderia conceber que o Estado fosse, ao mesmo tempo, "o construtor e o explorador de serviços". Em sua opinião, o serviço telegráfico brasileiro "não está monopolizado; o Estado cuida do interesse público desenvolvendo (...) as suas linhas, e estabelecendo taxas muito módicas, que facilitem o emprego do mais rápido meio de comunicação" ${ }^{2}$. Na prática, porém, prevaleceu a idéia do "monopólio republicano", defendida pelo engenheiro Francisco Bhering, especialista no assunto e então diretor da RGT, que consistia na obediência aos planos do governo, na fiscalização do serviço telegráfico pela autoridade federal, e em manter para a União a prerrogativa de desapropriar linhas e estações telegráficas construídas pelos Estados e por companhias particulares.

$\mathrm{Na}$ verdade, o que estava em questão era a centralização, nas mãos da administração pública, do direito de definir o programa de ação e o funcionamento das comunicações telegráficas, bem como de organizar os projetos para ampliação das linhas, e de realizar ou supervisionar a construção de linhas telegráficas em todo o território nacional. Estes temas deveriam seguir um plano geral da rede telegráfica, elaborado pela repartição técnica responsável pela administração dos telégrafos nacionais, tendo em vista os interesses do Estado ${ }^{13}$. As unidades da federação interessadas em construir linhas telegráficas, dentro dos limites de seus territórios, deveriam encaminhar requisição ao governo federal e concorrer com, pelo menos, a metade do valor orçado para as despesas da construção.

Apesar do esforço em manter sob o controle do Estado esses meios de comunicação modernos - telégrafo, telefones, rádio -, eles não deixaram de ser objeto de intensa disputa entre a iniciativa privada e o poder público. Dentre as justificativas para o monopólio do Estado sobre os meios de comunicação, destaca-se o argumento da necessidade de vencer a distância entre o litoral e o sertão e o atraso econômico e cultural do interior do país. Os meios de comunicação deveriam ser instrumentos, nas 
mãos do Estado, para promover a ocupação produtiva do interior, para garantir a posse definitiva das fronteiras com países vizinhos e a efetiva integração de regiões distantes da capital federal. Além disso, os inventos técnicos eram pensados como instrumentos capazes de promover a civilização e o desenvolvimento econômico do país. Ferrovias e telégrafo foram utilizados muitas vezes como desbravadores e pioneiros, antecedendo a ocupação e a colonização dos sertões brasileiros. Acreditava-se mesmo que a simples construção de uma estrada de ferro ou de uma linha telegráfica tivesse o poder quase mágico de transformar tudo a sua volta. Como observou Pierre Denis, geógrafo francês, por volta de 1909:

os brasileiros constroem estradas [de ferro] em pleno deserto, em virtude de um princípio verificado nos Estados Unidos, de que as estradas desenvolvem as regiões que atravessam, e que o colono, o industrial e o comerciante seguem atrás das locomotivas... [a ferrovia] age como uma artéria vivificante.... Novos caminhos abertos terminam na estação, perto da qual surge logo um pequeno centro comercial: hospedaria, armazém, farmácia, etc. Poucos anos depois tudo aquilo já é uma cidade florescente nascida como por encanto. ${ }^{14}$

O telégrafo foi entendido de forma semelhante. Nas cidades ele revolucionaria o comércio, a indústria e o mercado financeiro, agilizando a troca de informações e auxiliando no transporte de mercadorias. No interior ou nos sertões, sua utilidade estaria associada às noções militares de defesa do território, do governo e administração de populações dispersas, de manutenção da ordem e progresso da nação. Esta era a visão do marechal Rondon, comandante de expedições militares que construíram milhares de quilômetros de linhas telegráficas nos Estados de Mato Grosso, Acre e Amazonas nos primeiros anos do século XX:

onde quer que chegue o telégrafo ... ali far-se-ão sentir os benéficos influxos da civilização. Com o estabelecimento da ordem, obtida pela facilidade com que os governos podem agir [para] distribuir o bem público e a justiça, virá fatalmente o desenvolvimento do homem e das indústrias. ${ }^{15}$

Integrar os espaços ditos vazios do país através da construção de linhas telegráficas e de um projeto de colonização transformou-se em uma bandeira republicana, empunhada por grupos de engenheiros militares que, imbuídos da fé positivista na Ciência e na Técnica, pretendiam acelerar a marcha evolutiva do país. Na medida em que o telégrafo - com sua 
rede de postes, fios e estações -, marchasse rumo ao oeste desbravando e amansando sertões, ele levaria também a palavra do poder tornando palpável a idéia de nação e de República até os confins do território nacional ${ }^{16}$. Embora a telegrafia não fosse atraente para os investidores privados - pelo alto custo da construção e instalação das linhas, pelas dificuldades no trabalho de construção, ou devido às tarifas altas em virtude das longas distâncias -, houve disputas em torno de sua exploração e controle. Desde que o telégrafo elétrico foi instalado no Brasil, em 1852, os dois maiores concorrentes do serviço telegráfico público foram as companhias de estradas de ferro e os cabos submarinos costeiros construídos pela empresa americana Western Telegraph Company. Ligando o Brasil aos EUA e Europa, a Western monopolizava a fatia mais rentável da comunicação telegráfica: a correspondência comercial urgente e a quase totalidade dos telegramas internacionais. As estradas de ferro, que construíram aproximadamente 17.000 quilômetros de linhas telegráficas, possuíam aparelhos telegráficos em cada uma de suas estações e competiam diretamente com as agências telegráficas públicas, disputando o serviço telegráfico interno. Elas operavam com tarifas mais baixas, além de oferecer horários de atendimento mais amplos, aumentando a procura pelos seus serviços. Para a RGT, sobravam os investimentos em linhas menos importantes nas quais, muitas vezes, as despesas eram maiores que a receita arrecadada em função do pequeno volume de telegramas expedidos.

Vale notar também as diferenças entre telégrafo e telefones no que se refere à atração de capitais particulares e à constituição do monopólio estatal no setor de comunicação. Os telefones foram, desde o início, objeto de disputas entre particulares pelas concessões para construção e operação de linhas, e foram rapidamente incorporados como um bom investimento por parte das empresas privadas. A facilidade e simplicidade no estabelecimento desse serviço e a maior procura do público pelas ligações telefônicas, em comparação com as mensagens telegráficas, talvez expliquem o interesse da iniciativa privada pelo setor de telefonia em todo o país. A construção de linhas telefônicas também ficou sob a responsabilidade da RGT, conforme resolução de abril de 1880. Apesar de ter o domínio exclusivo do setor, o Estado podia fazer concessões para a exploração dos serviços telefônicos. E, a partir de 1882, quando foram distribuídas as autorizações para construir e explorar as primeiras redes telefônicas em cidades de norte a sul do Brasil, a concessão às empresas particulares, nacionais e estrangeiras, organizadas para explorar a comunicação telefônica, tornar-seia a regra na administração do setor de telefonia. 
Nos primeiros anos do século $\mathrm{XX}$, já existiam em todas as capitais brasileiras e na maioria das cidades importantes companhias que ofereciam serviços de telefonia, quase sempre explorados por empresas particulares, que administravam as linhas e as centrais para ligações. Em Cuiabá, por exemplo, em 1913, a central telefônica da Empresa Telefônica Cuiabá, de propriedade de João Pedro Dias, concessionário do serviço havia menos de 10 anos, atendia a 200 assinantes e já anunciava para breve sua ampliação para 350, com a instalação de novos equipamentos importados dos EUA. Considerando que a população da cidade totalizava cerca de 30 mil habitantes e que Cuiabá ainda não possuía sequer um serviço público regular de iluminação elétrica, tem-se a dimensão da relativa agilidade com que a iniciativa privada se organizava em torno da exploração da telefonia.

Num primeiro momento, a compra de aparelhos e a assinatura do serviço esteve restrita a uma parcela da população que, fascinada pela agilidade e facilidade deste meio de comunicação, transformou o telefone num ícone e num símbolo de distinção social. Grande parcela do público, no entanto, era atendida por meio de cabines públicas instaladas nas centrais telefônicas. De todo modo, a relativa facilidade do funcionamento dos telefones e o progressivo barateamento do custo dos aparelhos am140 pliaram o número de usuários e fizeram crescer o volume de ligações e a necessidade de investimentos em linhas e equipamentos.

Ao contrário da telefonia, o telégrafo não se constituiu como setor atraente para os investidores, seja em virtude da flutuação do seu público usuário - particulares e empresas -, que acompanhava as retrações do comércio e as crises financeiras; seja pelo alto custo da construção e instalação das linhas; pelas grandes distâncias entre as localidades; dificuldades das obras de construção; ou pelas altas tarifas dos telegramas em virtude das longas distâncias a percorrer. Em virtude da exigência de conhecimento técnico e domínio de um código de linguagem próprio, a constituição do público usuário do telégrafo se dá pelo consumo dos serviços sem a possibilidade de transformá-lo em adorno. O caminho de sua apropriação e popularização, portanto, foi marcado por aspectos distintos e caracterizou-se pela acirrada disputa em torno da concessão de autorização para a instalação de cabos fluviais e marítimos e pela divisão do volume de correspondência interna e externa.

O empenho da RGT era no sentido de construir a afirmação do "telégrafo nacional" como uma modalidade distinta do serviço telegráfico particular, procurando ampliar seu alcance ao expandir suas linhas e estações por todo o território nacional. Ao mesmo tempo em que se constituía um monopólio do Estado sobre os meios de comunicação, justifi- 
cado pela necessidade de integrar a nação, vencer a distância geográfica e redimir o interior do país do seu atraso material e cultural, expandia-se fisicamente a rede telegráfica pública num grande esforço de penetração do território. Esse processo de interiorização das comunicações via telégrafo é uma marca da República, que enfatizou a construção de linhas, ramais e sub-ramais, criando uma trama de redes e estações para interligar as capitais já atingidas pelo telégrafo com as cidades menores dentro dos Estados, além de desenvolver linhas de "internação" ou "expansão" capazes de fechar os circuitos telegráficos internos. Os meios de comunicação foram apropriados pelo Estado como os instrumentos disponíveis para promover a ocupação do interior, a nacionalização e a republicanização do Brasil. O telégrafo tornava-se um dos índices para aferir o progresso e o avanço civilizador no país. A instalação de agências telegráficas foi objeto de disputas políticas solicitadas com insistência e transformaram-se em elementos distintivos do desenvolvimento material das cidades brasileiras.

Para avaliar a presença desse serviço público na vida urbana do período, basta assinalar que o serviço telegráfico nacional já empregava, em 1930, 6 mil funcionários - dos quais cerca de 1.700 eram telegrafistas distribuídos por 1.450 estações telegráficas em todo o território nacional. Isto equivale a dizer que, apesar dos percalços, a RGT iniciava essa década com 59 mil quilômetros de linhas telegráficas ligando todos os Estados da Federação, unindo municípios, vilas e povoados interioranos numa verdadeira rede de comunicações rápidas que, juntamente com o telefone e o rádio, sem esquecer os correios, estava enfeixada nas mãos do Estado nacional. A constituição da comunicação telegráfica - como um ramo da administração pública - adquiria uma organização e um desenvolvimento comparáveis apenas à distribuição de forças militares envolvidas com a segurança nacional.

O telégrafo já significava muito mais do que simples "veículo rápido e silencioso das ordens dos governos e das medidas táticas e estratégicas dos exércitos e marinhas" ${ }^{\prime 17}$. Os números organizados pela repartição indicam o seu crescimento contínuo, sua transformação em um órgão público com abrangência nacional e uma crescente aceitação dos seus serviços. Podemos pensar que a instalação de cada estação telegráfica significava mais um passo na oficialização da comunicação telegráfica, e pode ter sido apresentada como um dos instrumentos de integração nacional por meio das comunicações, de modo a vencer o isolamento de grupos, etnias, espaços e tempos diferenciados existentes no país.

É possível explorar ainda o que esse crescimento e a constituição do telégrafo, como um "serviço público", representaram em termos de en- 
cargos para o Estado: a necessidade de criação de uma organização burocrática e administrativa de âmbito nacional; a padronização de cargos e carreiras técnicas; os investimentos na formação e qualificação profissionais através da organização de escolas, com oferta de cursos técnicos e aulas práticas para o treinamento de toda a mão-de-obra empregada. Considerando as dimensões continentais do país, a dispersão de sua população em cidades e vilas distantes centenas de quilômetros umas das outras, pode-se avaliar melhor o que esse crescimento representou em termos de um projeto de integração do território nacional e de suas populações.

Ao mesmo tempo, tem-se uma rápida imagem do desafio imposto à RGT, dividida entre a necessidade de ramificar as linhas por vastas áreas desertas - mesmo que elas atendessem apenas a um número insignificante de despachos telegráficos - visando à constituição de uma malha de estações para o fechamento de um circuito nacional, e pressionada pela urgência em atender aos serviços de conservação e renovação das linhas - tronco do litoral, cujo movimento crescia rapidamente.

Por outro lado, as estatísticas organizadas anualmente pela RGT indicam o crescimento constante do número de telegramas enviados, e também a ampliação do número de palavras utilizadas para compor os textos das mensagens. A minúcia dos dados reunidos permite acompanhar o ritmo da circulação de telegramas no país - de pouco mais de um milhão, em 1900, para nove milhões em 1940. Uma leitura possível desses números traduz o investimento constante no aperfeiçoamento técnico dos aparelhos telegráficos, na padronização dos procedimentos e na intensificação dos ritmos dos trabalhos nas agências, agilizando a transmissão de um maior número de palavras por minuto. Mas eles sugerem também questões interessantes, e que venho investigando neste projeto, em torno das possibilidades de ampliação da comunicação telegráfica e do lento processo de constituição do seu público usuário, pouco a pouco familiarizado com os códigos da escrita telegráfica.

É possível ainda indagar, por exemplo, sobre como essas linguagens e meios de comunicação se articularam historicamente criando formas de comunicação e de dominação através dos seus respectivos suportes técnicos que, apropriados por grupos sociais, organizaram e definiram o acesso às informações, idéias e imagens, moldando comportamentos e orientando as relações sociais. Compreendendo o suporte técnico necessário à comunicação telegráfica - o aparelho telegráfico, os fios, os postes e as estações - como um elemento indissociável da natureza mesma da linguagem por ele criada, creio ser possível investigar as especificidades e os significados da linguagem produzida pelo telégrafo, explorando dimensões de uma linguagem nova, em formação, que precisa constituir- 
se, ganhar público, concorrer com outros meios de comunicação já existentes, como os correios ou o telefone.

Nesse sentido, venho tentando acompanhar o processo de constituição da comunicação telegráfica, os esforços no sentido de criar uma padronização para esta linguagem, e de popularizá-la junto às populações urbanas, a partir tanto da atuação da Repartição Geral de Telégrafos quanto de diferentes iniciativas desenvolvidas em outros espaços do social, tais como jornais e revistas de grande circulação, almanaques diversos, códigos e outros guias para ensinar a "passar telegramas”, etc. A intenção é investigar como se construiu e como se apresentava, para o público das duas maiores cidades brasileiras de então - Rio de Janeiro e São Paulo -, essa popularização do telégrafo, seus usos e funções, e qual o impacto na paisagem e no cotidiano urbanos dessa rede de postes, fios e estações, necessária à comunicação telegráfica. Não se trata evidentemente de buscar apenas as marcas na aparência das cidades, mas também as imposições e necessidades de uma maior organização dos espaços urbanos até então desconhecidas ou pouco significativas - como o endereço correto e identificável, possível de ser localizado corretamente através dos nomes das ruas e numeração das casas.

\section{NOTAS}

* As idéias aqui expostas integram uma pesquisa mais ampla, em andamento, sobre a popularização do telégrafo e da linguagem telegráfica intitulada "Telégrafo, cultura e vida urbana: Rio e São Paulo (1890-1930)”, com a participação dos bolsistas Francis Alves Manzoni e Luciano Marconi Mattioli, e financiamento do PIBIC/CNPq. Outras questões foram discutidas no primeiro capítulo de minha tese de doutorado, A nação por um fio: caminhos, práticas e imagens da Comissão Rondon, defendida na PUC-SP, em fevereiro de 1997.

${ }^{1}$ BHERING, Francisco. A radiotelegraphia no Brasil: elementos históricos. Rio de Janeiro: Imprensa Nacional, 1914, p. 326. Grifos meus.

${ }^{2}$ WILLIAMS, Raymond. Marxismo e literatura. Rio de Janeiro: Zahar, 1979, p. 43.

${ }^{3}$ FENELON, Dea Ribeiro. “Cultura e História Social: historiografia e pesquisa”. Projeto História, São Paulo, n⿳ 10, dez. 1993, p. 86.

${ }^{4}$ Brasil. Ministério da Justiça. Relatório do ministro Eusébio de Queiroz Mattoso, ministro e secretário do Estado, apresentado em 1850. Grifos meus.

${ }^{5}$ SENNA, Ernesto. O Telegrapho no Brazil. Rio de Janeiro: Typ. do Jornal do Comércio, 1904, pp. 5-11. O autor, além de funcionário da Repartição Geral de Telégrafos, era também "repórter-prodígio" e "caça-notícias” do Jornal do Comércio, do qual foi redator desde o início do século XX.

${ }^{6}$ Brasil. Ministério da Justiça. Relatório do ministro José Thomaz Nabuco de Araújo, ministro e secretário de Estado, apresentado em 1854, pp. 31-34. 
${ }^{7}$ Esta é a versão republicana para o descrédito enfrentado pelo telégrafo durante o Império, repetida em diversos relatórios administrativos, como por exemplo: Repartição Geral de Telégrafos. Relatório de 1902 apresentado ao ministro da Indústria, Viação e Obras Públicas, pelo diretor-geral Caetano César de Campos. Rio de Janeiro: Imprensa Nacional, 1905, pp. 143146.

${ }^{8}$ A efetiva ligação do Brasil à Europa pelo telégrafo só ocorreu em 1874, com a instalação do cabo submarino ligando Pernambuco a Portugal, realizada pela empresa The Western Telegraph Company Limited, organizada inicialmente pelo barão de Mauá e transferida para capitalistas ingleses. $\mathrm{Na}$ inauguração desse cabo transatlântico, o governo imperial, em reconhecimento aos serviços prestados por Mauá, "fê-lo visconde, como o fizera barão ao inaugurar-se a nossa primeira estrada de ferro". Cf. BHERING, Francisco. A radiotelegraphia no Brasil, op. cit., p. 340.

${ }^{9}$ LIBÓRIO, Pedro. Os nossos serviços telegráficos civis durante o século. Rio de Janeiro: Officina Graphica do Jornal do Brasil, 1923, p. 7. As duas referências seguintes encontram-se nas páginas 6 e 4, respectivamente.

${ }^{10}$ Brasil. Repartição Geral dos Telégrafos. Relatório apresentado ao ministro da Indústria, Viação e Obras Públicas, sobre o ano de 1900, pelo eng. Álvaro de Mello C. de Vilhena. Rio de Janeiro: Imprensa Nacional, 1902, pp. 72-73.

${ }^{11}$ Brasil. Repartição Geral dos Telégrafos. Relatório da Repartição Geral dos Telégrafos do ano de 1907 apresentado ao ministro da Indústria, Viação e Obras Públicas pelo diretor geral interino Euclides Barroso. Rio de Janeiro: Imprensa Nacional, 1909, p. 28.

${ }^{12}$ Cf. Comentários de João Barbalho Uchôa Cavalcanti à Constituição Federal, e Viveiros de Castro. "Tratado da Ciência da Administração". Apud: BHERING, Francisco. A propósito da jurisprudência telegraphica. Rio de Janeiro: Typ. Leuzinger, 1915, pp. 11-17.

${ }^{13}$ É significativo que o primeiro plano republicano para a expansão da rede telegráfica nacional retomasse não só os propósitos de interiorização como as direções traçadas nos projetos esboçados no Império. Além disso, a discussão sobre essas questões foi deslocada para o interior do Ministério da Guerra, ainda que a Repartição Geral dos Telégrafos fosse administrativamente vinculada ao Ministério da Indústria, Viação e Obras Públicas. O plano republicano para o telégrafo está delineado no Decreto $\mathrm{n}^{\circ} \mathrm{22}$, de 24 de outubro de 1891.

${ }^{14}$ DENIS, Pierre. O Brazil no século XX. Lisboa: José Bastos e Cia. Editores, s.d., p. 71. Grifos meus.

${ }^{15}$ RONDON, Cândido M. da S. Mato Grosso. O que ele nos oferece e o que espera de nós. Conferência realizada a 31 de julho de 1920 perante a Sociedade Rural Brasileira. São Paulo: s.ed., 1920, p. 22. Grifos meus.

${ }^{16}$ Os ideais de republicanização do País embasaram a organização e a atuação das comissões militares comandadas pelo marechal Rondon - que passariam à história como a 'lendária Comissão Rondon' -, para a construção de linhas telegráficas no oeste brasileiro entre 1900-1915. Ver: MACIEL, Laura Antunes. A nação por um fio: caminhos, práticas e imagens da Comissão Rondon. São Paulo: EDUC/FAPESP, 1999.

${ }^{17}$ MOREIRA, Livio G. Telegraphia — Noções Práticas. Curityba: João Haupt \& Cia., 1924, $2^{\underline{a}}$ ed., p. 5. 